\title{
EFFECTS OF DIFFERENT CASING ONTO THE YIELD OF BUTTON MUSHROOM
}

\author{
Gergely SZUKÁCS, ANDRÁs GeÖSEl
}

\author{
Szent István University \\ Department of Vegetable and Mushroom Growing \\ Ménesi str. 44., 1118 Budapest, Hungary \\ Szukacs.Gergely@kertk.szie.hu
}

\begin{abstract}
In Europe and Hungary Agaricus bisporus is the most widely cultivated mushroom. Because of the competition on the market and the increasing costs of production is necessary to optimize the cultivation conditions and develop its intensive production technologies. The casing of the substrate is a critical and essential part of the intensive cultivaion technologies. The casing layer is important because it helps to protect the substrate from some pathogens and also balances the alternating temperature. More than $90 \%$ of the button mushroom fruitbody is water and thus mainly supplied by the casing. This casing soil contains the essential microbiota for primordia formation like Pseudomonas putida which has an important role in pin head stage. Casing soils origine from different source, mainly bogs or fens. The major component of casing soil is usually some kind of peat, like Sphagnum peat or black peat and lime. There is many contradiction about the effect of this casing soils onto the mushroom production during cultivation. In this study, we collected 7 different casing soils from farmers and casing soil producers (1 Dutch, 2 Polish, 2 Romanian and 2 Hungarian) and monitored the changes of its electric conductivity (EC) and $\mathrm{pH}$ during a small-scale cultivation, and examined this casings effects onto the yield. According our experiment the $\mathrm{pH}$ had been decreasing and the electric conductivity had been increasing during the cultivation. There were no significant differences between the casings in the total yield, but our results underlined that quality of casing has a major importance in the mushroom cultivation.
\end{abstract}

Keywords: casing soil, Agaricus bisporus, electric conductivity, pH, yield

\section{INTRODUCTION}

In the last decades the mushroom production in the World increased dramatically, significant jump was observed in the last 10 years. The mushroom production worldwide growth is over 27 million tons/year. It means that average mushroom consumption has been increased from $1 \mathrm{~kg} /$ capita to $4 \mathrm{~kg} /$ capita/year. The most widely cultivated mushrooms are Agaricus spp. These take a part of $30 \%$ of the world's mushroom production (ROYSE, 2014). In Europe and Hungary the commonly cultivated mushroom species is Agaricus bisporus. In our country the share of the species is around $92 \%$ (FRUITVEB, 2015). On one hand, the increasing amount of production on the other hand the cultivation costs and competition on the market underline the importance of optimalization of the growing technology.

In button mushroom (Agaricus bisporus) cultivation an important step is the casing of the substrate, because of several reason. The fruit bodies of button mushroom contain about $90 \%$ of water and this is mainly provided by the casing layer. Growing of the mycelium is positively infulenced by the high $\mathrm{CO}_{z}$ concentration that is also served by the casing material (ERDEI, 1999). This substrate is also a reservoir for the microbiota, like Pseudomonas putida which has an important role in pin heading stage (COLAUTO ET AL., 2016; OUdEN, 2016). Casing layers can protect the substrates against some patogens and dramatic temperature changing as well. 
In Europe, casing soils are usually made from mixed peats and lime, but peats are origin from very different places, like bogs and fens. These areas are serving different peats, like black peat or Sphagnum in different quality. We have some practical knowledge about the optimal casing, but there is a lack of information about its general quality and effects on the button mushroom yield. We would gather information about this phenomenon because we will run out of peat needed for mushroom production and we should find some potential material to replace it.

\section{MATERIAL AND METHOD}

In this study, 7 different casing soils originating from different countries were collected: 1 Dutch, 2 Polish, 2 Romanian and 2 Hungarian type of material were tested. A small scale cultivation experiment was conducted by using Phase 3 (bulk-colonized) compost. The 7 different casing soils were placed on the compost in $5 \mathrm{~cm}$ thickness and 8 replicates were used. The compost bags were placed in a growing a room as a block design. The crop rurned for 35 days and casing samples were taken on every $5^{\text {th }}$ days. Its $\mathrm{pH}$ and EC (electric conductivity) were measured by Hanna Instruments HI $2550 \mathrm{pH} / \mathrm{ORP}$ \& EC/TDS/ $\mathrm{NaCl}$ Meter. The yield achieved on different casings were also noticed, by measuring the fruit body weight on each picking day.

\section{RESULTS}

\section{Electric conductivity (EC)}

During the cultivation, the EC level was measured as it shown on Figure 1. On this graph the curve of EC can be seen. We concluded that initial value of the casing soil might be important because high deviation depending on origin was detected.

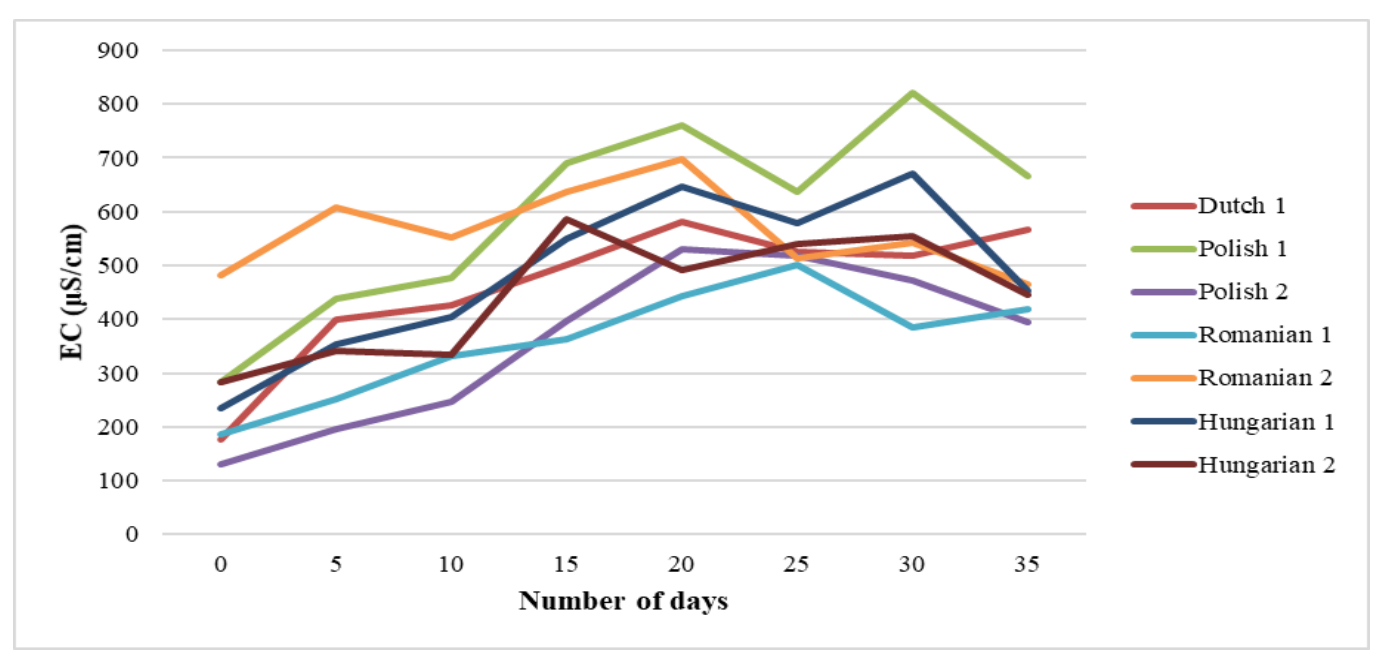

Figure 1. Monitored EC under cultivation

In the first part of the cultivation, the Polish 2 casing had the lowest EC $(130,5 \mu \mathrm{S} / \mathrm{cm})$ and the Romanian 2 had the highest one $(481,5 \mu \mathrm{S} / \mathrm{cm})$. These values did not reach the 1000 $\mu \mathrm{S} / \mathrm{cm}$ level in the first days of the cultivation, wich has influence on the yield according to AHDB (2011). During the cultivation, the electric conductivity increased slowly. At the end of the cultivation the highest value was shown by Polish 1 casing soil $(666 \mu \mathrm{S} / \mathrm{cm})$ and lower level was shown by Polish $2(394 \mu \mathrm{S} / \mathrm{cm})$ casing material. The final EC value of the 
casing materials did not reached the critical value so from this point of view the casings are fine.

\section{pH level}

The value of $\mathrm{pH}$ was also measured during the cultivation. It is shown in Figure 2. At the begining of the cultivation, $\mathrm{pH}$ levels of the casing soils were above 7 . The Dutch 1 had the highest $\mathrm{pH}$ (7.66), but Romanian 1 had almost the same (7.65). The Hungarian 1 had lower level (7.04). Most of the literature suggests that optimal $\mathrm{pH}$ for mycelia growing is between 7.5-7.6 (JARIAL ET AL., 2005; GYÖRFI, 2010). The farmers should pay attention to keep the $\mathrm{pH}$ value above 7 because under 7 there is a more sensitive environment for Trichoderma spp. infection (OUDEN, 2016). Unfortunately, the $\mathrm{pH}$ of each casing soils drop under 7 on the 10th day of cultivation. It may explain why are there more infections at the later stages of button mushroom cultivation.

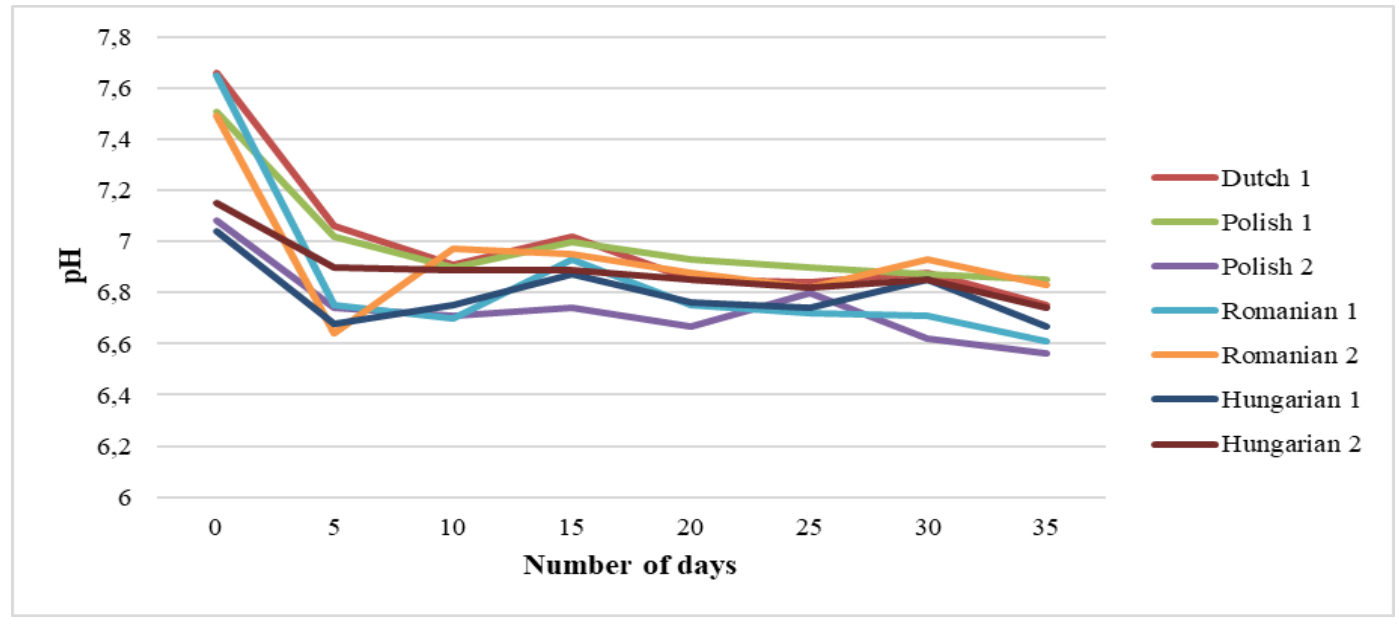

Figure 2. Changing of $\mathrm{pH}$ under cultivation

\section{Yield of the Cultivation}

In the course of the 35 days of cultivation we checked the development of mycelia and picked the mushroom fruitbodies daily. First mushrooms appeared between 18th and 21th days of the cultivation. On Figure 3 the aggregated yield can be seen. The average yield of the different casing soils was very similar meaning that basically there was no difference between the fruit body production of the different casing soils.

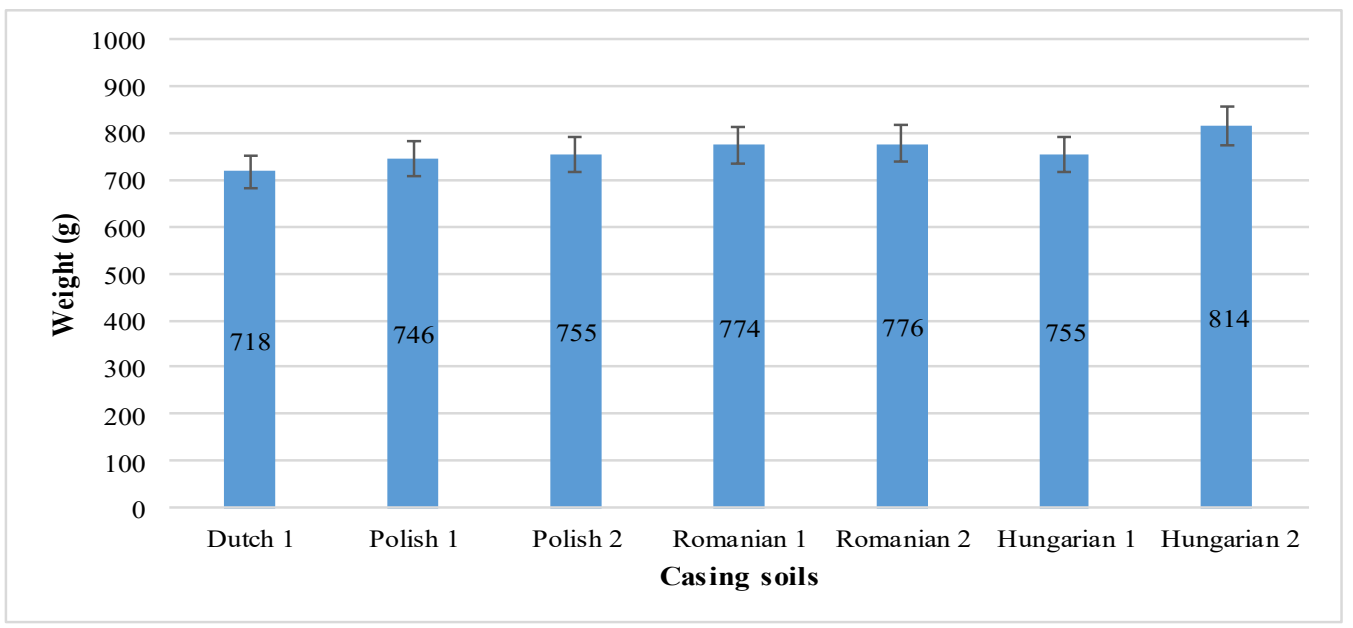

Figure 3. Average yield of different casings 


\section{CONCLUSIONS}

Casing soils used in mushroom cultivation may originate from very different places and their components are very heterogeneous, but mainly contain peats and lime. Although their quality is an important factor of successful cultivation, we do not have enough information about the casings wich are used in cultivation.

According to our results, starting EC values of casing soils are different, but they are between 100-500 $\mu \mathrm{S} / \mathrm{cm}$. During the cultivation EC is increasing, and at the end of the cultivation usually does not reach the $1000 \mu \mathrm{S} / \mathrm{cm}$ value. The highest value was $666 \mu \mathrm{S} / \mathrm{cm}$. According to the report of AHDB (2011), the critical value is $1000 \mu \mathrm{S} / \mathrm{cm}$. Other researches found that EC is suitable for mushroom cultivation to $5000 \mu \mathrm{S} / \mathrm{cm}$, it will only delay pinheading and the development of mushrooms (OUDEN 2016).

Values of $\mathrm{pH}$ are still very different in csaing soils. These fluctuate between 7.04 and 7.66. According to literatures, optimal $\mathrm{pH}$ values are between 7.5-7.6 (GYÖRFI, 2010). During the cultivation $\mathrm{pH}$ is decreasing under 7 , in our study the lowest value was 6,56 . The falling $\mathrm{pH}$ is in correlation with the added lime because, it is used to increase and stabilise the $\mathrm{pH}$. A further study is needed that target constant $\mathrm{pH}$ by alkaline watering and examine the effect on the yield and the rate of infections, mainly over the first flush.

Focusing on yield there was no significant diference between the casing soils. According to our study, all the tested casing soils were suitable for button mushroom cultivation.

\section{ACKNOWLEDGEMENTS}

We would like to say thank you, for the helping hands to Mariann Füri, and all the other people who helped in the mushroom picking. Also thank you for the casing soil donates.

Supported by the ÚNKP-17-2 New National Excellence Program of the Ministry of Human Capacities.

\section{REFERENCES}

AHDB (2011): Grower summary, mushrooms: Desk study/literature review of the potential alternative materials to peat in mushroom casing. Agriculture \& Horticulture Development Board. Final Report 2011.

Colauto, N.B., Fermor, T.R., EirA, A.F., Linde, G.A. (2016): Pseudomonas putida stimulates primordia on Agaricus bitorquis. Current Microbiology 72(4): 482-488.

ERDEI, B. (1999): A takaróföld szerepe a gombatermesztésben és a hazai takaróanyag minőségi paraméterei: Gomba Híradó 3(13): 16-17.

FrUitVEB (2015): A zöldség és a gyümölcs ágazat helyzete. FruitVeB, Budapest. Pp. 1718.

GYÖRFI, J. (2010): A csiperkegomba (Agaricus bisporus) termesztése. In: Győrfi J. (ed.). Gombabiológia, gombatermesztés. Mezőgazda kiadó, Budapest.

JARIAL, S.R., SHANDILYA, R.T., JARIAL K. (2005): Casing in mushroom beds - A review. Agricultural Review 26(4): 261-271.

OUDEN DEN, M. (2016): Mushroom signals. A practical guide to optimal mushroom growing. Mushroom Office, s-Hertogenbosch.

Royse, D.J. (2014): A global perspective on the highfive: Agaricus, Pleurotus, Lentinula, Auricularia, \& Flammulina. Proceeding of the 8th International Conferenceon Mushroom Biology and Mushroom Product (ICMBMP8) 20th November 2014, New Delhi. Pp. 1-6. 